\title{
Searching for Common Ground: Jews and Christians in the Modern Middle East
}

\author{
H.L. Murre-van den Berg
}

In the late 1990s, the taxi driver of a Tehran cab changed the cassette tape to the engaging sounds of the Hebrew song Hava Nagilah ('Let us rejoice'), a Jewish favorite for festive occasions. Not quite knowing whether I was being provoked into anti- or pro-Israel sentiments, I somewhat cowardly indicated approval without asking for details. While the tape played on, the conversation was not pursued further, and I later asked some Iranian friends what they made of it. They laughed at my discomfort and told me Israeli music was quite popular in Tehran and easily procured at the bazaar. As long as politics were kept out of it, the culture of the archenemy was not a problem. It was only later that I learned about the thriving music culture in Iran and in the Arab Middle East of which Jews and Christians formed an intrinsic part. Especially in Iran, Jewish ensembles were popular among all classes of the population and Hava Nagilah was often performed at weddings, even after the majority of Jews left Iran in the years following the Islamic Revolution.

While the link between this earlier musical scene and the 1990s interest in Israeli music is perhaps an indirect one, both phenomena point to music as a locus of interaction and sharing even between communities that are antagonistic. Often, this thriving and thoroughly mixed music culture has been quoted as an example of how people of different religious communities in the Middle East could live and party well together, sharing a common local culture. The Tehran example indicates that this may have been too rosy a picture of how these societies functioned in the past and present, not only because shared cultural practices do not necessarily imply shared outlooks on society, but also because even seemingly innocent songs have political overtones that might not always be shared by those who pass them on, but which remain part of the song's afterlife for those who want to see it. ${ }^{1}$ At the same time, cultural practices

1 The song Hava nagila (composed in Palestine, 1920s) has a nationalist ring, with the vocabulary of the refrain 'uru, ahim,' 'Awake, brothers,' echoing, among others, George Antonius' title and motto on Arab nationalism (taken from a nineteenth-century poem by Ibrahim Yazeji, 
such as these continue to be used and interpreted as my friends interpreted them, as a sign of communality over borders created by religion and politics. It is precisely this ambiguity, between the political and the ostensively neutral, that provides space for the participation of those to whom politics proper would otherwise be closed off.

This volume discusses cultural practices that in different ways constituted common ground between the various groups that made up Middle Eastern, especially Arab Middle Eastern societies in the late nineteenth and early twentieth centuries. It does so based on the premise that such cultural issues never constitute a separate domain apart from political and economic participation, but that they are part and parcel of patterns of interaction with all kinds of political implications. These cultural practices, therefore, address issues of power and presence of the so-called minorities in multiple ways. Thus, without dealing with the political participation of non-Muslims in Muslim dominated states as such, this volume aims to focus on the ways in which non-Muslims contributed to creating and developing spaces of encounter. These spaces of encounter sometimes took the form of actual political debates, but also took the form of literal spaces of encounter with public rituals or participation in language and educational reform. It is these types of common ground that constitute the main theme of this volume.

The contributors of this volume all participated in a conference that was organized in September 2013 by a Leiden research group based in the Institute for Religious Studies at the Faculty of Humanities, in cooperation with LUCIS, the Leiden Centre for the Study of Islam and Society. This research group, funded by the Netherlands Organization for Scientific Research (NwO) works on a project entitled Arabic and its Alternatives: Religious Minorities in the Formative Years of the Modern Middle East (1920-1950). The project's focus is mostly on the British mandate areas of Iraq and Palestine, and this is reflected in the fact that most contributions to the conference and in this volume have the same strong focus on these two emerging states. This introduction and some of the contributions make a start in contextualizing the ways in which non-Muslims in the British mandate areas acted and were acted upon against the background of the larger Arab Middle East, also in French Mandate

"Arise, ye Arabs, and awake"), Antonius, The Arab Awakening: The Story of the Arab National Movement (London: Hamish Hamilton, 1938). Compare also Naum Fayiq's poem in Classical Syriac, "Awake, Son of Assyria" (1920), see David Gaunt, "Relations between Kurds and Syriacs and Assyrians in Late Ottoman Diyarbekir," in Joost Jongerden, Jelle Verheij, Social Relations in Ottoman Diyarbekir, 1870-1915 (Leiden: Brill, 2012), 250. 
areas. For that reason, the Maghreb is explicitly included, with its vibrant Jewish communities in mostly French-ruled contexts. This inclusion allows for a comparison of the two largest non-Muslim communities not only in contexts where the two communities lived alongside each other, but also where one of them dominates the local scene.

Rather than merely introducing the main themes of the search for common ground as described by this volume's authors, this introductory article pays special attention to the developments within the Christian communities, parallel to Schroeter's article on the Jewish communities. Over the last decades, the interwar developments of the Middle Eastern Christian communities have attracted considerable research attention. Thorough work has been done on the Coptic Christians in Egypt, ${ }^{2}$ as on Palestine's Christians, often from the perspective of the wider nationalist movement, but not exclusively so. ${ }^{3}$ Recently, the Assyrians in Iraq and Iran, after many years of near neglect, have found historians to write their story. ${ }^{4}$ The post-World War I history of the Armenian, Syriac Orthodox and the various Catholic communities of Lebanon, Syria and Iraq, however, is scantily covered. Especially Lebanon's Christian history is usually subsumed in more inclusive narratives that do not always topicalize a specific 'Christian' experience. ${ }^{5}$ While this is understandable from the perspective of those who want to emphasize the inclusive nature of Lebanese history, it

2 Vivian Ibrahim, The Copts of Egypt: The Challenges of Modernisation and Identity (London/ New York: I.B. Tauris, 2011); Heather Sharkey, American Evangelicals in Egypt: Missionary Encounters in An Age of Empire (Princeton: Princeton University Press, 2008).

3 Laura Robson, Colonialism and Christianity in Mandate Palestine (Austin: University of Texas Press, 2011), Noah Haiduc-Dale, Arab Christians in British Mandate Palestine: Communalism and Nationalism, 1917-1948 (Edinburgh: Edinburgh University Press, 2013), Roland Löffler, Protestanten in Palästina. Religionspolitik, Sozialer Protestantism und Mission in den deutschen evangelischen und anglikanischen Institutionen des Heiligen Landes 1917-1939 (Stuttgart: Kohlhammer 2008).

4 Sargon George Donabed, Reforging a Forgotten History: Iraq and the Assyrians in Twentieth Century Iraq (Edinburgh: Edinburgh University Press, 2015), David Wilmshurst, The Martyred Church, A History of the Church of the East (London: East \& West Publishing, 2011).

5 Asher Kaufman, Reviving Phoenicia: the Search for Identity in Lebanon (London: I.B. Tauris, 2004/2014); For a specific focus on the Armenians, see Nicola Migliorino, (Re)Constructing Armenia in Lebanon and Syria: Ethno-Cultural Diversity and the Sate in the Aftermath of a Refugee Crisis (New York: Berghan Books, 2008). A recent thesis addresses Maronite identity in this period via the analysis of literary production: Amaya Martin Fernandez, "National, Linguistic, and Religious Identity of Lebanese Maronite Christians through their Arabic Fictional Texts during the Period of the French Mandate in Lebanon" (Ph.D. diss Georgetown University, 2009). 
obscures both the many links to and the important differences between the Christian history of the various Arab countries. Before discussing the major themes of this volume from such a comparative and historiographic perspective, a number of crucial concepts that underlie the discussion need to be introduced. The most important of these are minority, modernity and the public sphere.

\section{Minority, Modernity, and the Public Sphere}

The term 'minority', as common as it is nowadays, in actual usage but also in its implied meanings is inextricably connected to twentieth-century nationalism. As has been shown for the emerging state of Syria, the term 'minority' started to be used in the context of the formation of the nation state, in a fluid context in which different identities vied for prominence, and in which international dynamics, especially those connected to the League of Nations, played a major role.

While in today's parlance Jews and Christians are seen as prototypical minorities in the Muslim world, this was generally not the case when the term started to be used in the period following World War I. In fact, most Christians and Jews would resist the term and the accompanying political isolation that came with it, seeing it as an imposition from the mandate governments in Egypt and Syria, often linked to earlier policies of Western protection of Christian and Jews. An imposition, that is, that denied their longstanding cultural and economic participation as well as limiting their possibilities of political participation in the new states. ${ }^{6}$ Especially in Egypt, Coptic Christians successfully resisted the label 'minority' precisely to ensure their position at the heart of the debates about the future of the Egyptian state. ${ }^{7}$ In their rejection of a spe-

6 Benjamin Thomas White, The Emergence of Minorities in the Middle East: The Politics of Community in French Mandate Syria (Edinburgh: Edinburgh University Press, 2011); Gudrun Krämer, "Moving out of Place: Minorities in Middle Eastern Urban Societies, 1800-1914," in Peter Sluglett (ed.), The Urban Social History of the Middle East, 1750-1950 (Syracuse, NY: Syracuse University Press, 2008), 182-223; Tsolin Nalbantian, "Going Beyond Overlooked Populations in Lebanese Historiography: The Armenian Case," History Compass 11, no. 10 (2013): 821-832.

7 See especially Saba Mahmood, Religious Difference in a Secular Age: A Minority Report (Princeton/Oxford: Princeton University Press, 2016); Mahmood discusses minority discourses in Egypt against the background of larger discussions about the state, secularism and exclusion, both in the Middle East and Europe. 
cial minority status, these Jews and Christians distanced themselves from other groups who for internal and external reasons came to identify as minorities, like the Assyrians in Iraq and the Armenians and Syriac Orthodox in Lebanon and Syria. Not coincidentally, most of them were recent arrivals in the new nation states, which explains at least some of the mutual suspicion and hostility. In this volume, the contributions by Robson and Müller-Sommerfeld deal with the complicated process of minoritization of the Assyrians that took place in mandate Iraq.

Gradually, however, the term minority began to refer more and more to all Christians and all Jews, whatever their origins and cultural-linguistic backgrounds. Despite these non-Muslims' legal rights resulting from full citizenship (at least for most of them), they were not seen as belonging to the core of the nation state and often were excluded formally or informally from crucial positions. Processes like these have been described for Palestine, about which both Sanchez Summerer (this volume) and Haiduc-Dale stress the agency of Christians (who mostly sided with Muslim Palestinian nationalists) and Druze (who were more easily brought over to the Zionist side) in defining what kind of minority they wanted to be. ${ }^{8}$ Also the Copts, in the later decades of the twentieth century, started to revert on their rejection of the minority label, if only to ensure governmental protection and international support.

Discussions about minoritization are the flip side of those about the communalities undergirding the nation state. In the so-called 'Arab provinces' of the former Ottoman Empire (Syria, Lebanon, Egypt, Iraq, Jordan and Palestine), state formation following World War I led to an ongoing debate about what exactly are the characteristics of the model citizen..$^{9}$ While the concept of the 'Arab' state seems to presuppose an Arab ethnicity ('race' in the terms of the time) as the basis of the nation state, the debate over what 'Arab' was,

8 In addition to Haiduc-Dale's Arab Christians, see also his "Rejecting Sectarianism: Palestinian Christians' Role in Muslim-Christian Relations," Islam and Christian-Muslim Relations 26, no. 1 (2015): 75-88. Robson (Colonialism and Christianity) stresses the importance of British policy that divided Palestinian society along religious lines.

9 Nadine Méouchy, Peter Sluglett, Gérard D. Khoury, The British and French Mandates in Comparative Perspectives / Les mandats français et anglais dans une perspective comparative (Leiden: Brill, 2004); Peter Sluglett, Britain in Iraq: Contriving King and Country (London: Tauris, 2007); Sami Zubaida, "The Fragments Imagine the Nation: The Case of Iraq," International Journal of Middle East Studies 34, no. 2 (2002): 205-215; Elizabeth Thompson, Colonial Citizens: Republican Rights, Paternal Privilege, and Gender in French Syria and Lebanon (New York: Columbia University Press, 200o), Kais M. Firro, Inventing Lebanon: Nationalism and the State under the Mandate (London; New York: I.B. Tauris, 2003). 
who could be counted as Arab, and what the status of non-Arabs in these states should be, was by no means resolved. Does 'speaking Arabic' count as 'being' Arabic? Who is allowed to 'become' Arab, and who wants to become Arab?10 Meanwhile, the debate over religion that had already started in the Ottoman Empire in the nineteenth century continued. Does one need to be a Muslim to be a full citizen? And if not, on what grounds could non-Muslims participate in these societies?11 These ongoing debates underline that who is and who is not a 'minority' is never clear-cut, is bound to change over time, and can and will be consciously changed by those involved.

When talking about the 'Arabness' of the region's Christians, often the term 'Arab Christians' is used. However, this term is rather vague, often including all Christians that historically or in the contemporary period used Arabic in their communities, the language of liturgy, written communication and literature, if not also as a spoken vernacular. ${ }^{12}$ Such a definition then would include the Syriac and Coptic communities who used Arabic alongside Syriac or Coptic, the Maronites who were almost completely Arabic-speaking and writing but differ greatly to what extent they consider themselves ethnically 'Arab', and the Greek Orthodox and Greek Catholics, who may still use Greek in the liturgy, but are overwhelmingly Arabic-speaking and writing and in the contemporary period tend to see themselves as ethnically Arab. Thus, in the modern period, Arab Christians is mostly a blanket term for Christians from the majority of churches in the Middle East that are literate in Arabic and often also use an Arabic vernacular, regardless whether they consider themselves ethnically Arab or not. However, it could also be used polemically in nationalist discussions, to gauge one's stand on 'being' an Arab or not, supporting Arabism in some of its forms, or not. Suffice it to say that, as we shall see further on, being described as

10 James Jankowski and Israel Gershoni (eds.), Rethinking Nationalism in the Arab Middle East (New York: Columbia University Press, 1997); Yasir Suleiman, The Arabic Language and National Identity (Washington, DC: Georgetown University Press, 2003); Peter Wien, Iraqi Arab Nationalism: Authoritarian, Totalitarian and Pro-Fascist Inclinations, 1932-1941 (soAs/Routledge Studies on the Middle East, 2006), Adeed Dawisha, Arab Nationalism in the Twentieth Century: From Triumph to Despair (Princeton: Princeton University Press, 2003).

11 Bruce Masters, Christians and Jews in the Ottoman Arab World: The Roots of Sectarianism (Cambridge: Cambridge University Press, 2001); Ussama Makdisi, A Culture of Sectarianism: Community, History, and Violence in Nineteenth-Century Ottoman Lebanon (Berkeley: University of California Press, 200o).

12 So David Thomas' essay 'Arab Christianity' in Ken Parry (ed.), The Blackwell Companion to Eastern Christianity (Malden, Oxford and Victoria: Blackwell Publishing Ltd, 2007), 2-22. 
an 'Arab Christian' does not automatically imply supporting Arab nationalism and even less implies identifying as 'Arab'.

In an attempt to avoid the ambiguities and contingencies implied in the term 'minority', often the term 'community' is used. For most of the authors in this volume, Jewish and Christian 'communities' indeed form the starting point of their analyses. However, the term 'community' brings with it its own set of questions, most importantly whether or not the concept of 'community' is malleable and changeable according to circumstances and therefore just as slippery for analysis as 'minority.' While this is certainly true in an absolute sense (communities change in outlook, characteristics, and size), in the states under discussion here, 'communities' are usually defined by the less subjective notion of legal categories. The term 'community' thus follows the legal structures of the states under investigation, structures that were inherited from the Ottoman Empire and before, structures that assign a legal status to one's religious belonging. ${ }^{13}$ As an aside, it is important to note that when interpreting 'community' as roughly the translation and modern continuation of the Ottoman millet, important differences between the two concepts are glossed over. First, in many ways millet, in the nineteenth-century pre-Tanzimat sense, had the clear meaning of referring to those groups that occupied social and political subordinate positions vis-à-vis the majority of Muslims, rather than to different religiously or ethnically defined subgroups in general. Also after these groups were officially granted equal rights in the Ottoman state, they continued to be seen as separate millets, whereas Muslims were not. ${ }^{14}$ Second, not all non-Muslim communities were considered a millet in the way other non-Muslims were: Maronites,

13 Krämer, "Moving out of Place"; Schroeter and Goldstein-Sabbah in this volume. As such, communities can also be counted, by their own leaderships as well as by the state. However, reliable statistics are few and far between. In general it is assumed that over the whole of the Arab Middle East, Christianity declined from about 20 percent of the population in the early twentieth century to less than 5 percent towards its end. Despite the tremendous human impact of the genocide of Armenian, Syriac, and Assyrian Christians in the eastern Ottoman provinces, the main factor for decline in Christians is the lower population growth of Christians in relation to that of Muslims, see Hannelore Müller, Religionen im Nahen Osten 1: Irak_Jordanien—Syrien_Libanon (Wiesbaden: Harrasowitz Verlag, 2009).

14 See Robson (Colonialism and Christianity) on this process in Palestine; according to her analysis, the British applied the Ottoman millet system to Muslims also, effectively creating an additional millet. While millet in this new sense is certainly a new phenomenon for the Muslim community, it must be noted that the term millet had been used for Muslims before the nineteenth century, when the terms millet and țaifa were less strictly defined and hence could also be used for the Muslim sub-group of the population. 
Druze, and Assyrians living outside the direct reach of Ottoman tax collectors and state officials enjoyed a social and political independence unimaginable for non-Muslims at the heart of the Ottoman state. This included the right to carry arms and fight along their Kurdish or Druze neighbors that belonged to the same tribal federations. ${ }^{15}$ Thus, while the relationship to the state differed between millets and the majority of Muslims, as well as between raya (subservient 'flock') and ashiret (independent clans), the importance of the community was the same for pretty much everyone. Belonging to such a group was predicated on and governed by overlapping religiously-inspired legal frameworks that mutually reinforced each other and bound people to the group in which they were born.

Though the rhetoric about the abolishment of the millet-system might suggest otherwise, not only did these legal structures survive in the new nation states, but often their importance increased under the influence of colonial and post-colonial bureaucratic demands. Put differently: legal equality between the different communal groups was to be strived for, but not the disappearance of the formal barriers between the groups. Based on the religion of one's father (or mother, in the case of Jews), every person 'belonged' to a religious community, a belonging that in most states was and continues to be explicitly mentioned on one's identity papers. Independent from personal devotion or active communal identification, this legal status, unless explicitly changed by conversion, positions its members within a specific community. This implies that the religious leaders of these communities have power over important issues such as marriage, child custody, divorce, inheritance issues, and burial. ${ }^{16}$ While such 'communities' also change over time, the legal framework precedes any interpretation of these groups as 'minority', by themselves or by others. These legally defined communities therefore form a workable starting point for analysis, precisely in order to be able to describe the varied positions members of these communities (in the legal sense) take in the societies to which they belong.

\footnotetext{
15 Joachim Jakob, Ostsyrische Christen und Kurden im Osmanischen Reich des 19. und frühen 20. Jahrhunderts (Vienna: LIT Verlag, 2014), Géraldine Chatelard, Briser la mosä̈que: les tribus chrétiennes de Madaba, Jordanie, XIXe-XXe siècle (Paris: CNRS éditions, 2004).

16 Legal systems in many of the contemporary states of the Middle East are built along the same lines; this is true in Israel, Lebanon, Jordan, Iraq, and Syria; see, e.g., Chibli Mallat, "The Lebanese Legal System," in The Lebanon Report (1997) 2, 29-44; Esther van Eijk, "Family Law in Syria: A Plurality of Laws, Norms, and Legal Practices," (PhD thesis, Leiden, 2013), and Michael M. Karayanni, "Two Concepts of Group Rights for the PalestinianArab Minority under Israel's Constitutional Definition as a 'Jewish and Democratic' State," International Journal of Constitutional Law 10, no. 2 (2012): 304-339.
} 
The formation of the nation states, so important in understanding the concept of minority, also begs a brief discussion of the modernization processes that took place in the Middle East. If anything, changing concepts of community and especially of people's expectations of their participation in the states to which they belonged are closely tied to the monumental changes that took place between $185^{\circ}$ and 1950, from the early days of the Tanzimat in the Ottoman Empire, to the independent Arab states created in the 1930 s and $1940 s$. These changes included new expectations of education with regard to professional and personal development, of changing gender roles including women's participation in society, of social care and standards of health, of literature and popular culture as much as expectations of new standards of religious devotion, training, and leadership, and, indeed, of societal participation and democracy. In an intricate interplay between Western (including Russian) influences via missionaries, welfare organizations, literary exchanges and political, economic, and diplomatic ties, and local demands and pressures at the local and state levels, the Arab provinces of the Ottoman Empire started to look for ways to reorganize their society. ${ }^{17}$

As Keith Watenpaugh describes, the modernization processes that took place in the late nineteenth and early twentieth centuries first and foremost created a middle class that embodied the ideals just referred to. ${ }^{18}$ This class consisted of Muslims as well as Jews and Christians, though Jews and Christians made up a disproportionally large part of them: they, more than Muslims, had access to new forms of education, and via education to new kinds of jobs, new kinds of literature, and thus to new ideas about society, both within their own communities and with an eye toward the wider society. Among these ideas were also those about the importance of Arab identity and the

17 On the nineteenth-century processes, including the impact of western missionaries, see Ussama Makdisi, Artillery of Heaven: American Missionaries and the Failed Conversion of the Middle East (Ithaca/London: Cornell University Press, 2008), Heleen Murre-van den Berg, New Faith in Ancient Lands: Western Missions in the Middle East in the Nineteenth and Early Twentieth Centuries (Leiden: Brill, 2006), Razmik Panossian, The Armenians: From Kings and Priests to Merchants and Commissars (New York: Columbia University Press, 2006), Adam Becker, Revival and Awakening:American Evangelical Missionaries in Iran and the Origins of Assyrian Nationalism (Chicago: Chicago University Press, 2015), and Paul Sedra, From Mission to Modernity: Evangelicals, Reformers and Education in Nineteenth Century Egypt (London: I.B. Tauris, 2011); further Schroeter, Massot, and Goldstein-Sabbah in this volume.

18 Keith David Watenpaugh, Being Modern in the Middle East: Revolution, Nationalism, Colonialism and the Arab Middle Class (Princeton, NJ: Princeton University Press, 2006). 
Arab nationalism that accompanied it, alongside other nationalisms of the day, Turkish, Armenian, and Assyrian.

One further aspect of this modernization process that accelerated in the early twentieth century is the modernization of religion and religious practice. As recently described by James Grehan, perhaps the most important and influential domain where different communities mixed, mingled, and shared, was that of religious practice. Outside formal prayer services in churches, mosques, and synagogues, but often with the involvement of religious leaders such as priests, imams, and rabbis, there existed a domain of religious practices that were shared by all in the region, regardless of religion and religious community. The veneration of saints, the practice of 'magic,' and an elaborate repertoire of bodily movements, were practiced by Christians, Jews, Druze, Sufis, Sunnī and Shī'a Muslims, often with rather little differentiation as to narrative interpretation. ${ }^{19}$ In the late nineteenth and early twentieth century, religious reformers of all religions increasingly began to interpret these practices as oldfashioned, uninformed, rural, and superstitious. Such interpretations led to an increase in the standardization of religion with regard to theological teaching and ritual practices as much as with religious institutions such as schools and church buildings, and a decline of such practices that very visibly erased borders between religions. ${ }^{20}$ Notably, many of the practices survived until the present day, either unacknowledged or scorned by the religious establishment, or integrated into more 'acceptable' religious practices. Obviously, in the modernist interpretations of 'common ground,' which has been the starting point of the contributions in this volume, this older form of shared cultural practices is no longer considered relevant, even if it continues to exist and may even constitute an alternative ground for communality between religious groups. In many cases, however, these sacred spaces become locations of contestation, over religious modernization, in service of ethnic and national belonging. ${ }^{21}$

\footnotetext{
19 James Grehan, Twilight of the Saints: Everyday Religion in Ottoman Syria and Palestine (Oxford: Oxford University Press, 2014).

20 In the missionary modernization project these themes played a crucial role; see the studies mentioned in n. 17 .

21 Dionigi Albera and Maria Couroucli. Sharing Sacred Spaces in the Mediterranea (Bloomington, IN, Indiana University Press, 2012), Glenn Bowman, Sharing the Sacra: The Politics and Pragmatics of Intercommunal Relations around Holy Places (New York, NY: Berghahn Books: 2012). On Christian politicization of the Holy Sepulcher/Church of the Resurrection, see Raymond Cohen, Saving the Holy Sepulchre: How Rival Christians Came Together to Rescue their Holiest Shrine (Oxford: Oxford University Press, 2008).
} 
While the above is certainly too brief a summary of the extensive and sophisticated debates that have taken place in analyzing processes of modernization and nation formation, the basis that undergirded the idea for this volume and the conference that preceded it, is that these changes enabled and encouraged Christians and Jews to rethink their position in society. It is from this rethinking that, implicitly or explicitly, many of the cultural practices that are described in this volume arose.

What further resulted from these modernization processes was a reshaping of the actual and metaphoric space where debates over society could take place. While it would be a mistake to suggest that no public space between state and government on the one hand and the private sphere of family and close relations on the other existed in the Middle East before the twentieth century, the twentieth century indeed brought new forms and spaces, spaces in the Habermassian sense, where debates over the common good were open to the participation of those who wanted to be part of it. Social and literary clubs with mixed memberships (in term of gender and religion), newspapers in standardized languages, a powerful women's movement ${ }^{22}$ and non-sectarian political parties all brought new participants to a discussion that before the twentieth century would have been conducted in much smaller and more closed circles, such as the houses of the ruling elites, (all-male) coffeehouses, sharia courts, religious schools, bathhouses, markets or religious festivals. This public sphere continued to evolve and change, but all of these changes allowed for a greater variety of people to be part of it, even if actual political participation, under mandate rule or under later autocratic Arab rulers, was still limited to a few. ${ }^{23}$

The way in which Jews and Christians, as part of the majority or as minorities, participated in the emerging Arab states was characterized by a variety of

22 For an overview, see Ellen L. Fleischmann, "The Other 'Awakening': the Emergence of Women's Movements in the Middle East, c. 1900-1940," in Karen Offen (ed.), Globalizing Feminisms, 1789-1945 (London and New York: Routledge, 2010), 89-139. Among many others, see also Ellen L. Fleischmann, The Nation and Its "New" Women: The Palestinian Women's Movement, 1920-1948 (Berkeley: University of California Press, 2003); Marina Warner, Memoirs of an Early Arab Feminist: The Life and Activism of Anbara Salam Khalidi (London: PlutoPress, 2013; Arabic original, Beirut 1978).

23 Miriam Hoexter, Shmuel N. Eisenstadt, Nehemia Levtzion (eds.), The Public Sphere in Muslim Societies (Albany: State University of New York Press, 2002); Peter Sluglett (ed.), The Urban Social History of the Middle East, 1750-1950 (Syracuse, NY: Syracuse University Press, 2008); Seteney Shami, Publics, Politics and Participation: Locating the Public Sphere in the Middle East and North Africa (New York: Social Science Research Council, 2009); also Schroeter in this volume. 
actions that are often overlooked when talking about the public sphere. It is in the variety of such actions, from public mourning to participation in Arab literary culture, from rap music to political demonstrations, from a preference for French-language education to moving to newly-built mixed neighborhoods, from political and cultural assimilation to the majority to the separatist nationalisms of Assyrians and Armenians, that the full breadth of the societal choices of the various religious communities can be shown. In the following sections, four major themes of this volume will be discussed in more detail: the literal space of the urban landscape, the language (especially Arabic in educational contexts), the creation of national identities and the violence that often accompanied it, and, finally, transnationalism as a force to be reckoned with in the creation of national common ground. These four themes roughly correspond to the subdivision of the contributions to this volume, with Daniel Schroeter's introductory overview article on the Jews in the Middle East touching on all of these issues, as does the final article by Aomar Boum. His work on North African hip hop artists in many ways provides a counterpoint to the other essays, with its starting point in Muslim youth that use the transnational common ground of YouTube to address issues of exclusion and belonging, of political participation and political impotence. Note that while the main focus of this volume and its introduction is on the first half of the twentieth century, the analysis and some of the examples stretch back to the nineteenth century and move forward into the later twentieth and even early twenty-first century, in an attempt to look at these developments from a broader perspective than the mandate period as such.

\section{Urban Space and Public Presence: Performances of Community}

With images of the destruction of Syria's urban centers and historic monuments vividly in mind, one is reluctant to open Stefan Weber's magnificent two-volume work on the architectural history of Damascus in the nineteenth and early twentieth century. ${ }^{24}$ However, doing so is perhaps the easiest way of understanding something of the momentous changes that took place in the urban landscape of the Middle East in this period, in Damascus as well as in other cities of the region. His documentation of building activities such as the

24 Stefan Weber, Damascus: Ottoman Modernity and Urban Transformation (1808-1918) (Proceedings of the Danish Institute in Damascus, 2 vols.) (Aarhus: Aarhus University Press, 2009). 
sumptuous private homes in some parts of the Old City and the new neighborhoods outside the city, vividly illustrates the era of economic growth and population increase. More changed, however, than merely the scale and the luxury of urban planning. New types of buildings were allowed to appear, changing the outlook of the city in more fundamental ways. Some of these were connected to new institutions and public services, such as government buildings, post offices, and railway stations. Other buildings arose in conjunction with the increasing presence of westerners in the city, like consular buildings, missionary schools, and hospitals. And yet others embodied the socio-political changes of the period: new churches were built in the heart of the Old City.

While there had always been churches in Damascus, some more publicly visible than others, the Tanzimat reforms of the mid-nineteenth century made it possible for Christians to renew and expand their old buildings and to build new churches when and where they were needed. As described by Anais Massot in her article about Damascus in this period, the Christians of Damascus, supported politically and financially by western Christians, made ample use of these possibilities. Two neighborhoods of the Old City, one near Bab Tuma and the other between the Straight Street and Bab Sharqi, changed extensively with renewals of the Greek Orthodox patriarchate and new church complexes for the Armenians, Syriacs, and Greek Catholics. Similar changes also took place in Jerusalem, as they did in Beirut. ${ }^{25}$

Yet another form of non-Muslim public presence became much more common in post-Tanzimat times. Before the nineteenth century, Christian processions outside church grounds were rarely allowed. In her book on Copts in seventeenth-and eighteenth-century Egypt, Febe Armanios describes the spectacle of sending off a group of Christians making pilgrimage to the Easter festivities in Jerusalem, much the same way as Christians and Muslims would see off those embarking on the hajj to Mecca. ${ }^{26}$ When properly negotiated and paid for, such exceptions to the general rules of non-Muslim invisibility in the public domain were allowed; these occurred for the most part in neighborhoods that were predominantly inhabited by non-Muslims. After the Tanzimat reforms, such permissions were asked for and given more frequently, and this added another element to the public visibility of Jews and Christians.

25 See the contributions by Schroeter, Massot, and Wallach in this volume. For an analysis of more recent urban development in in multi-religious cities, see Chad F. Emmett, Beyond the Basilica: Christians and Muslims in Nazareth (Chicago: The University of Chicago Press, 1995).

26 Febe Armanios, Coptic Christianity in Ottoman Egypt (Oxford: Oxford University Press, 2011). 
Both Schroeter and Massot describe a third element of the rules of the newly emerging urban landscape, that of changing sartorial practices. Here the development is in the opposite direction, away from differentiation. Tanzimat reforms meant that clothing no longer served to differentiate the various groups of society. In earlier periods, certain clothing and colors, especially of headgear that generally served to identify a wide range of different ranks and functions of members of society, had been restricted to Muslims. More importantly, with the Tanzimat, men of all religions started to discard the various types of traditional gear, including turbans, in favor of the fez or, in Iraq, the siddara. This had begun in the nineteenth century; in the twentieth century, middle-class urban women of all religions followed by shedding the veil, removing yet another outward sign of gender and religious differentiation. As a result, individuals were less easily recognized as belonging to one community or another. At the same time, the religious communities as a whole became more visible in the public domain; they were allowed to build large complexes with churches and synagogues, schools, and hospitals. They also organized expressive public processions that showed off the differences between Christians of various kinds as much as between Muslims and non-Muslims. While this may seem contradictory, both the mostly unproblematic public display of Christian symbols and buildings, and the new sartorial practices underline the same basic point: modernization and its new norms of public presence started to override the importance of distinguishing between Muslims and non-Muslims. Notably, in the late 1970 s and early 1980 s, sartorial practices again started to reflect religious differences as much as regional and class differences, especially for women. Muslim women tended to take up 'Islamic' dress in its different forms while Christian women (if not forced by law or social pressure to dress 'Islamic') emphasized their freedom to dress 'western'. At the same time, however, they started to wear visible cross pendants to identify as Christian. ${ }^{27}$

Yair Wallach, in the context of early twentieth-century Jerusalem, discusses another aspect of the urban developments of the time, which is the emergence of new types of neighborhoods. In all of the cities featured in this volume, Damascus, Aleppo, Jerusalem, Beirut, Essouira, and Tunis, new neighborhoods were created outside the traditional city centers. In some cities such building activ-

27 Much has been written about the subtle codes of a variety of veiling practices, see among others, Jenny B. White, "The Paradox of the New Islamic Woman in Turkey" in Inger Marie Okkenhaug and Ingvild Flaskerud, Gender, Religion and Change in the Middle East. Two Hundred Years of History (Oxford/New York: Berg, 2005), 123-136, Julia Droeber, The Dynamics of Coexistence in the Middle East: Negotiating Boundaries Between Christians, Muslims, Jews and Samaritans. (London: I.B. Tauris, 2013). 
ities had already begun in the nineteenth century, and took off in earnest in the early twentieth century. These new middle-class neighborhoods exemplified a new ideal of living, with freestanding buildings, preferably for individual families (even if extended family living remained the norm), with gardens surrounding them instead of the closed inner courtyards of the traditional houses. Important for our discussion today, as also described by Wallach with regard to his main protagonist Gad Frumkin, is the fact that these neighborhoods were much more mixed as to religion than was the case in the old city centers. Though most of the old neighborhoods were not strictly segregated (see Wallach's description of Jerusalem, where he counters the popular images of a city divided into four distinct neighborhoods), many neighborhoods would indeed have a majority population of one religion, with small groups of families belonging to other religions. What bound the inhabitants of these new neighborhoods together was not the earlier communal concerns, but their shared vision of what modern life should entail.

For many, these changing ideals about modern life included ideals about the nation state, also when the fundamental principles of the new states were yet to be negotiated. The ways in which the Jewish community of Baghdad participated in the mourning ceremonies over the death of two successive monarchs, King Fayșal in 1933 and King Ghāzī in 1939, are indicative of their desire to be part of that newly emerging national community, in the varying political contexts of each event. Here the possibility of expressing itself publicly as a Jewish community emphasizes the community's adherence to national ideals and its symbols, symbols that in that period included the Hashemite monarchy's rule over Iraq. In her contribution, Aline Schlaepfer examines the Jewish community's sincere sympathy for Fayșal and much more cautious assessment of Ghāzī, then juxtaposes the two occasions of mourning, first for Fayșal, then the much more expressive mourning for Ghāzī. Her analysis underlines the political rather than emotional nature of these public stagings of grief: at the time of Fayșal's death, the Jewish community still felt relatively secure about their own position in Iraqi society, by the time Ghāzì died in 1939, the Iraqi government's flirtations with Nazism and the increased politicization of Zionism in the wider Arab world made it all the more important to express, as publicly and explicitly as possible, their adherence to the Iraqi state's panArabist stance.

Such a message of 'religious harmony and solidarity' 28 has become a staple of the rituals of nation states in the Middle East and elsewhere, where occasions 
of grief, joy or external threat are used to express solidarity and conformity to the nation state. One of the earliest recorded events are the public celebrations, all over the Ottoman Empire, of the Young Turk Revolution in 1908. Everywhere people of different religions went out into the streets together, celebrating the constitutional changes that were expected to bring more freedom and more democratic rights to all citizens of the Ottoman state. These public demonstrations in support of Ottomanism were joined by people of all religions, but certainly not by everyone in every group. Wallach writes about Gad Frumkin, a young Ashkenazi Jewish journalist who reported on these celebrations in Jerusalem, where Sephardic Jews participated in great numbers, but Frumkin's own Ashkenazi peers were conspicuously absent. ${ }^{29}$ Here, in contrast to the mourning rituals described by Schlaepfer, participation was not communally staged, and might have been mostly an individual affair. Clearly some parts of the Jewish community were much more interested in these new Ottoman ideals than others.

These changing relationships between the various communal components of the Ottoman Empire and its successor states constituted also a cause for violence that often has been interpreted as 'intercommunal.' Massot's detailed analysis of the context of the events in Damascus in 1860, when Christians in the Old City quarters were murdered and much of their property was looted and destroyed, shows that this is a far too easy generalization. Indeed, the eighteenth century and the early part of the nineteenth century saw an increased politicization of the various non-Muslim communities, a politicization that created what has been called a 'sectarianism' different from the forms of communal identity that existed in the eighteenth century and before. This new type of communal politics included, among other things, foreign protection of various communities, with the British extending protection to Jews and Druze, the French to the Eastern and Oriental Catholic Christians, and the Russians to the Greek ('Rum' or 'Antiochian') Orthodox. Such political protection, by virtue of earlier treaties between the Ottoman Empire and foreign states, also brought economic benefits, at least for some. It is the combination of political empowerment with economic advances that made the changes of the nineteenth century difficult to bear for those Muslims who in the process lost political and economic power. Therefore, as Massot argues, it was no coincidence that those hardest hit by the events of 1860 in Damascus were those Christians with the most obvious foreign connections and those who profited most visibly economically, i.e., those living in the prominent newly renovated neighborhoods

29 Wallach (this volume) bases himself on Frumkin's journal. 
of Bab Sharqi and Bab Tuma rather than those living in more modest quarters in the Maydan (Midan) neighborhood. While indeed Muslims attacked Christians, the conflicts are much better explained by economic and social rivalries among certain parts of the population, where the increased opportunities for one group were envied by another, than by more general tensions between Muslims and Christians. ${ }^{30}$

\section{Arabic and Its Alternatives: Language and Education as Tools of Belonging}

When talking about 'common ground' and the role of the public sphere, the importance of a common language can hardly be overstated. In discussions on the emergence of the Arab states, therefore, the importance of Arabic is explicitly emphasized. More in-depth analyses, however, on types of Arabic and how they functioned as a means of communication between the various subgroups of these societies, are mostly lacking. ${ }^{31}$ Early nationalist authors such as George Antonius and Edmond Rabbath, in their English and French writings stressed the link between spoken Arabic and the Arab 'race,' with language and race together forming the basis of the ideology of Arab nationalism on which the emergent states were based. However, to account for the multiple

30 On the mid-nineteenth century violence in Lebanon/Syria, see Makdisi, A Culture of Sectarianism, and recently Feras Krimsti, Die Unruhen von 1850 in Aleppo: Gewalt im urbanen Raum (Berlin: Klaus Schwarz Verlag, 2014). Similar violence took place in the Hakkari Mountains (present-day Turkey) in the 1840 and 1850 ; no monograph has yet been devoted to it, but see the relevant chapters in J.F. Coakley, The Church of the East and the Church of England. A History of the Archbishop of Canterbury's Assyrian Mission (Oxford: Clarendon Press, 1992), John Joseph, The Modern Assyrians of the Middle East: Encounters with Western Christian Missions, Archaeologists, and Colonial Powers [Studies in Christian Mission 26] (Leiden: Brill, 200o), and Wilmshurst, The Martyred Church.

31 For an extensive discussion of the relationship between Arabic and Arabic nationalism, see Yasir Suleiman, The Arabic Language and National Identity (Washington, DC: Georgetown University Press, 2003), and from the same author, Arabic in the Fray: Language Ideology and Cultural Politics (Edinburgh: Edinburgh University Press, 2013). For a recent overview of a more strict sociolinguistic approach, see Reem Bassiouney, Arabic Sociolinguistics: Topics in Diglossia, Gender, Identity, and Politics (Edinburgh: Edinburgh University Press, 2009). For the Lebanese case, see John E. Joseph, Language and Identity: National, Ethnic, Religious (New York: Palgrave Macmillan, 2004) and Franck Salameh, Language, Memory, and Identity in the Middle East: The Case for Lebanon (Lanham, MD: Lexington Books, 2010). 
ways in which Arabic was part of the different communities that made up the states they envisaged (Syria, Lebanon, Palestine), Arab nationalists allowed for a rather flexible interpretation of what counted as Arabic, and, more importantly, for 'assimilation' and 'devenir arabe' with regard to culture and ethnic belonging. ${ }^{32}$ Thus 'being Arab' was not necessarily an essentialist given, even if, ultimately, 'Arabness' was measured against a community's link with the ultimate Arabness of the Arabian Peninsula. ${ }^{33}$ However flexible this nationalist ideology may have been (intended as it was to include as many groups as possible), it needed a clearly defined form of practiced Arabic to support it. This 'Modern Standard Arabic' (MSA, or fuṣha), as it came to be called, was to function as a measuring rod for the degree of commitment to Arabness, as a symbol for a unity that did not yet exist.

However, the success of Modern Standard Arabic depended on the fact that, true to its origins in the eighteenth- and nineteenth-century literary renewal, it was much more than a nationalist tool. ${ }^{34}$ The standardized form of the Classical Arabic language emerged when the need for new types of learning and communication grew outside the bounds of traditional religious learning based on the holy writs of Islam, Christianity, and Judaism. Members of literary and journalistic circles transcended religious and regional differences and further developed this particular form of Arabic that gradually, sometime between the early and final decades of the nineteenth century, became the lingua franca of the Middle East. As a lingua franca it was well placed to transcend a host of linguistic, religious, and ethnic differences that threatened the success of state formation. The successful duo that supported the emergent nationalism was, therefore, linguistic modernization and standardization supported by the modernization and standardization of education. It worked the other way round as well: successful nation building (with the help of and in opposition to the mandate powers) enhanced the importance of MSA through state support and control of education.

32 Rabbath, Unité Syrienne et devenier arabe (Paris: Marcel Rivière, 1937), 43, 97. On the related issue of the categories of 'race' and 'religion' in Palestine, see Jonathan Marc Gribetz, Defining Neighbors: Religion, Race, and the Early Zionist-Arab Encounter (Princeton: Princeton University Press, 2014).

33 Antonius, The Arab Awakening, 17. On Antonius' linguistic ideologies, see Heleen Murrevan den Berg, "The Language of the Nation: The Rise of Arabic among Jews and Christians (1900-1950)", British Journal of Middle Eastern Studies (2016), DOI: 10.1080/13530194.2016 .1138641 .

34 M.M. Badawi, Modern Arabic Literature (Cambridge: Cambridge University Press, 2006). 
It is essential, however, to keep in mind that the link between nationalism and educational and linguistic reform is by no means exclusive: a welldeveloped lingua franca can easily be put to other uses, usages that may easily contradict the tenets of particular nationalisms, be it in enabling rival political ideologies such as communism, pan-Arabism, and pan-Islamism, or in empowering subgroups to pursue their own specific aims-from a Christian interdenominational ecumenism to trans-regional business practices. The multiple functions of language, be they ideological, pragmatic or both, is one of the main themes of the essays in the second part of the volume. The role of Arabic in education, especially in private education as supported by western missionary and philanthropic organizations, and in private essays and letters, provides the starting point of the contributions by Sasha Goldstein-Sabbah, Karène Summerer-Sanchez, and Tijmen Baarda.

Before discussing in more detail the main conclusions of these three papers, the specific characteristics of the common ground we discuss in this section need to be delineated. Schools, especially those privately financed, constituted a particular kind of middle ground between public and private. As GoldsteinSabbah argues in her paper on Jewish education in Baghdad, the administration of the various Jewish schools consciously devised their curricula and their public presence with a view towards the Iraqi Nation, similar to (and partly in conjunction with) the way the community devised the public rituals discussed by Schlaepfer. Similar conclusions can be drawn from Sanchez Summerer's paper, which describes how Catholic schools in Palestine reacted to the changing times of the mandate period. In addition, the Catholic Palestinian schools, more so than those in Baghdad, also constituted places of encounter just by virtue of their mixed population of pupils from Jewish, Muslim, and Christian families. Put differently, the modern schools of the twentieth century became places where, on a small scale, the sometimes conflicting ideological and pragmatic aims of the sponsoring communities, parents, and wider public (including governments) had to be negotiated in order to arrive at a workable curriculum. Thus, what was negotiated in the schools reflected discussions in the religious communities themselves, with all the nuances and differences that came with it.

Two major conclusions emerge from the contributions of Sanchez Summerer, Goldstein-Sabbah, and Baarda. The first is that in the two very different contexts, that of the Jewish community in Baghdad and that of the Catholics in Jerusalem, teaching of (and in) Arabic increased considerably over time (with the support of the clergy, especially the Melkite patriarch), in order to keep pace with the increased importance of Arabic at all levels of society in both Iraq and Palestine. Basing himself on private correspondence within 
the Syriac community in northern Iraq, Baarda comes to a similar conclusion: here too the use of Arabic was widespread and its standardized form gained ground over and above non-standard forms. ${ }^{35}$ However, the second conclusion of these papers must be that the strengthening of Arabic in each of these three cases was less straightforwardly connected to nationalism and modernization than one may have expected, mainly for two reasons: the interference of and tensions with governments and external donors who favored languages other than Arabic, and the conflicting ambitions within the communities themselves.

In Palestine, the Catholic schools that were sponsored and organized by French congregations had to negotiate between the demands of the British Palestinian government and those of the local population. French, which had been an important language in Palestine until World War I, lost its status under the mandate, and the official languages of the country became Arabic, Hebrew, and English. Furthermore, the mandate system favored clear distinctions between the Jewish-Hebrew system on the one hand, and the ArabicPalestinian system on the other. The Catholic schools that had previously functioned mostly in a French-language context had to include English and more Arabic in their curriculum in order to provide their pupils with the means to function well in the local job market. In general, it seems that these developments were supported by the Arabic-speaking Catholics of Jerusalem, as they probably were by Muslim parents that sent their children to these schools. This change in focus implied that what in the nineteenth and early twentieth century had effectively become the francophonie of Middle Eastern Catholicism, now returned to its earlier arabophone leanings. As Sanchez Summerer notes, the Vatican, which sought the creation of an 'Arab' Christianity, supported this change. Ironically, French did indeed remain part of the curriculum, but mostly because of its worldly, rather than its religious benefits. ${ }^{36}$

35 While the importance of Arabic among the Jews of Baghdad has been noted earlier (see Goldstein-Sabbah and Schroeter in this volume), Schroeter points to the much more varied picture for the rest of the Middle Eastern Jewish world. In many other places, spoken forms of Arabic, and the written Judeo-Arabic, were replaced not by modern Arabic, but by French (in North Africa) and English, or by Hebrew; for Hebrew, see Wallach; note that his protagonist argued for better knowledge of Arabic in the Jewish community.

${ }_{3} 6$ On the importance of Arabic in the Catholic world of the seventeenth and eighteenth centuries, see Bernard Heyberger, Les chrétiens du Proche Orient au temps de la réforme catholique (Bibliothèque des Écoles Françaises d'Athenes et de Rome 284; Rome: École Françaises de Rome, 1994); Heleen Murre-van den Berg, "Classical Syriac, Neo-Aramaic 
In Baghdad, too, government pressures led to an increase in Arabic teaching, although the language had not been completely absent from Jewish communal schools in the nineteenth and early twentieth century. The Alliance schools, the most prestigious ones, with external funding, employed an Ottoman Turkish curriculum that also included French and Ottoman Turkish. However, Arabic also quickly gained importance in business and administration, perhaps more than it did in Palestine, and soon the schools wholeheartedly cooperated in increasing the amount and the level of Arabic. At the same time, as in Palestine, English was added to the curriculum, after having been nearly absent from most Baghdad schools.

As Goldstein-Sabbah notes in her overview of the Jewish communal school system, the time devoted to Arabic varied considerably from one school to another, with considerable differences not only between the more expensive Alliance schools and the much cheaper religious schools, but also between the boys' and girls' schools of the Alliance. By comparing these different curricula against the background of the governmental public schools, Goldstein-Sabbah differentiates between the various goals of language teaching within the Jewish community. Most goals were pragmatic and geared towards the future roles of boys and girls in and outside the Jewish community. Well-off families wanted their sons to know Arabic and English, because these were basic essentials needed to compete for jobs in public administration and commerce. Girls needed no such skills, and were taught high level French in addition to more homely subjects such as sewing, embroidery, and hygiene. Girls of the poorer families had little access to education; their parents had to make tough choices whether to send their male siblings to the governmental schools for a secular education in Arabic or to a free communal school that would teach mostly Hebrew and religion. While all of this appears to be the rather pragmatic outcome of needs and financial possibilities, Goldstein-Sabbah notes the interplay of these developments with larger changes in society. Not only was Arabic first introduced at a larger scale under government pressure in the 1920s, but when, in the 1940s, the nationalist rhetoric became more encompassing, all the

and Arabic in the Church of the East and the Chaldean Church between 1500 and 1800," in Holger Gzella, Margaretha L. Folmer (eds.), Aramaic in its Historical and Linguistic Setting (Veröffentlichungen der Orientalischen Kommission 50; Wiesbaden: Harrassowitz, 2008), 335-352; Carsten Michael Walbiner, "Some Observations on the Perception and Understanding of Printing amongst the Arab Greek Orthodox (Melkites) in the Seventeenth Century," in Philip Sadgrove (ed.), Printing and Publishing in the Middle East (Jss suplement 24) (Oxford/Manchester, 2008), 65-76; and Georg Graf, Geschichte der christlichen arabischen Literatur, 5 vols (Vatikanstadt, 1944-1955). 
schools increased their level of Arabic teaching, including the Laura Kadoorie girls' school and the religious Midrash Talmud Torah schools.

The growing importance of Modern Standard Arabic can also be examined from the perspective of the language itself. Baarda's contribution takes its starting point in the Syriac communities of Iraq, to see how scholars used the language in their correspondence in the 1920s. The two scholars whose Arabic he analyzes, Mattai bar Paulus of Mosul (1861-1947) and Nematallah Denno (1884-1951) both belonged to the Syriac Orthodox Church. Mattai was a deacon and an accomplished scribe of Syriac manuscripts, Nematallah presumably also knew Classical Syriac, the ecclesiastical language of the Syriac Orthodox Church. Despite their scholarly proficiency in Classical Syriac, both used Arabic in their writings: Mattai in his letters to Alphonse Mingana (c. 1870-1937), another Syriac scholar who had continued his career in Great Britain (Birmingham), Nematallah in a biographical note about Mattai that presumably was also sent to Mingana. ${ }^{37}$ As Baarda notes, such usage of Arabic for personal and scholarly communication is not unexpected, because in the Syriac Orthodox communities of northern Iraq, Arabic had long been established as a spoken vernacular and in the form of a substandard 'Middle Arabic' form for writing, including the translation of Classical Syriac texts. This form of substandard, dialectally influenced Arabic was, until the early twentieth century, usually written in Syriac script, and as such indicated by the term 'Garshuni.' In the twentieth century, the use of Garshuni quickly diminished, and standardized Arabic in Arabic script increased. It is surprising that Mattai and Nematallah used two diametrically opposed forms of written Arabic, in ways contrary to what we knew so far. Mattai writes with a well-formed Arabic handwriting, but includes a number of substandard grammatical forms that do not take into account the recent standardizations of Arabic. Nematallah, by contrast, writes in Garshuni but in perfectly standardized Arabic. Perhaps the explanation is to be found in different educational trajectories: Mattai was trained earlier in traditional schools and Nematallah, being younger, was educated in a more modern school. However, we know almost nothing about these two men's personal histories, so this remains conjectural. Even more conjectural are the possible reasons for the Garshuni in Nematallah's text. Did he want to impress Mingana with his Syriac handwriting? Or did he agree with those in the Syriac community who thought that for internal purposes clergy and scholars should use the Syriac script (even for Arabic) to express their solidarity with the Syr-

37 Nematallah's text ended up in the collection of Mattai's letters to Mingana in Birmingham; see Baarda in this volume for the details. 
iac Christian community? Or did he intend to emphasize his Syriac communal, nationalist, leanings? Or was the text originally addressed to a different, local northern Iraqi clerical audience that would have preferred Syriac script?

Whatever the reasons for Nematallah's remarkable choice of Garshuni, its mere occurrence alerts us to the fact that the general picture of a straightforward development in which Arabic becomes standardized and other languages lose ground, may need further refinement, if only to account for the erratic ways in which individuals at various points made their own choices. If anything, these examples, like the trajectories of the curricula of the communal schools in Baghdad and Jerusalem, make clear that the choice of Arabic was not necessarily one that was motivated by Arab nationalism, even if the Christians involved may have been loyal supporters of Iraqi or Palestinian nationalist aims.

\section{The Rough Edges of the Nation State: Between Belonging and Expulsion}

Common ground between the various communities that make up a nation cannot always be found. Many contributions in this volume touch on the negative side of the search for communalities, the failures, the stories of exclusion and expulsion, rather than integration. Peaceful coexistence or at the very least benign neglect were not always possible. Violence against non-Muslims, as discussed in Massot's article, usually arises from a complex interplay of socioeconomic and political factors, playing out on a particular subgroup, which in that moment embodies societal anxieties. The violence against Christians in the late nineteenth and early twentieth centuries included these same ingredients, but then became exacerbated by nationalist ideologies that generalized the violence to an extent these Christian communities had not yet experienced. It was mostly Turkish nationalism, in conjunction with the very real international pressures upon the Ottoman Empire from Russia, France and England that paved the way for the genocide on Armenian and Syriac Christians in Eastern Anatolia, Hakkari and northwestern Iran. The Christian communities of North Iraq, as well as those from Lebanon/Syria, were mostly spared —it seems that for the Young Turks, the Arab provinces warranted a different political regime. In addition, the Armenians had incurred Turkey's wrath by passively or actively supporting the Russians, hoping to gain some kind of independence out of it-providing yet another pretext for the wholesale expulsion of Armenians from Eastern Turkey, an expulsion in most cases accompanied by the gruesome murder of the adult men and followed by the deaths of many who were put on marches to the Syrian desert. 
Much has been written about the Armenian genocide, while the simultaneous massacres on Syriac, Assyrian and Chaldean Christians yet awaits full inclusion into the scholarly debate about this violent episode of Middle Eastern history. The expulsion and population transfer that befell the so-called 'Greek' Christians of Anatolia (who were mostly Turkish speaking) falls mostly outside the scope of this volume. ${ }^{38}$ What is especially relevant for the current volume, is the fact that many of the genocide survivors, especially those from the Armenian and Syriac communities, ended up in the Arab mandate states, in Palestine, Lebanon, Syria, Jordan and Iraq. Although there had been modest Armenian and Syriac communities in most of these countries, there numbers swelled considerably by the new arrivals. This was the case especially in Beirut and Aleppo which welcomed large Syriac and Armenian populations. In places like Jerusalem, Bethlehem and Amman, the communities were practically new.

While the actual civil status of these refugees differed from place to place and country to country, most at some point received citizenship and were officially integrated into the new states. However, despite the fact that often they were not so different from the Christian communities that had already longtime roots in a particular region, many of these communities assumed a low profile and in many respects can be seen as the first Christian minorities. Most came with little Arabic and preferred to maintain the language and culture of their Anatolian hometowns. Also after many had caught up on Arabic and had managed to build up their lives again, their connection to the new Arab states was fundamentally different from that of the Christians who had lived there for many generations. For most, and in most locations, a minority position that allowed for the development of separate Syriac or Armenian identities fitted their needs well. ${ }^{39}$

Such type of minority integration, however, did not fit the wishes of the Assyrians from Hakkari many of whom had ended up in a refugee camp in

38 On the Armenian genocide, Taner Akcam, A Shameful Act: The Armenian Genocide and the Question of Turkish Responsibility (London: Constable \& Robinson, 2007) Hans Lukas Kieser: Der verpasste Friede: Mission, Ethnie und Staat in den Ostprovinzen der Türkei, 1839-1938 (Zürich: Chronos, 200o); on the Syriac genocide, called Sayfo/Saypa ('Sword'), see David Gaunt, Massacres, Resistance, Protectors: Muslim-Christian Relations in Eastern Anatolia during World War I (Piscataway, NJ: Gorgias Press, 2006) and Florence HellotBellier, Chroniques de massacres annoncés: Les Assyro-Chaldéens d'Iran en du Hakkariface aux ambition des empire, 1896-1920 (Paris: Geuthner, 2014).

39 Heleen Murre-van den Berg, "A Center of Transnational Syriac Orthodoxy: St. Mark's Convent in Jerusalem," Journal of Levantine Studies 3, no. 1 (2013): 61-83, Migliorino, (Re)Constructing Armenia. 
Ba'quba. Their refusal to be integrated as Christian minority tragically ended in government-sanctioned massacre in Semele (North Iraq) in 1933. In several contributions to this volume, this event, which until recently had received rather limited academic treatment, is discussed. In current literature, the massacre of at least 360 disarmed men and a few women in the village of Semele by army troops led by army commander Bakr Sidqi (against a background of looting and killings in Assyrian villages in a wider area of north Iraq), is seen as a telltale event in the formation of the Iraqi state. ${ }^{40}$ While in Assyrian historiography the events have often been interpreted as the logical outcome of British betrayal in combination with long-term anti-Christian sentiments in Iraqi society, ${ }^{41}$ authors such as Husry and Zubaida stress the difficult position in which the Assyrians had placed themselves, a position that made them an easy target in a period of uncertain leadership and fierce discussions about the direction of the Iraqi state. At the time, many Iraqis understood the violence against these Assyrians as part of a national struggle against a rebellious group with British sympathies, a group that could count on little sympathy from the general population in Baghdad and other urban centers like Mosul and Basra, be they Christian, Jewish or Muslim.

As shown by Schlaepfer, in that context Bakr Sidqi's military actions worked in uniting the rest of population in support of the new government. The Assyrians themselves, though united in horror about what happened, were internally divided over the political course that had led to these massacres; many did not endorse the patriarch's attempt to advocate a separate status for the Assyrian Christian community, a status with greater legal and temporal powers for the

40 See the discussion of the literature by Sami Zubaida, "Contested Nations: Iraq and the Assyrians," Nations and Nationalism 6, no. 3 (2000): $363-382$ and my interpretation of the importance of the event for the Assyrians in Heleen Murre-van den Berg, "Light from the East (1948-1954) and the De-Territorialization of the Assyrian Church of the East," in Wim Hofstee and Arie van der Kooij (eds.), Religion beyond its Private Role in Modern Society (Leiden: Brill, 2013), 115-134. The earlier work of Joseph, The Modern Assyrians and Khaldun S. Husry, "The Assyrian Affair of 1933," International Journal of Middle East Studies 5 (1974), 161-176 (I) and 344-36o (II), as well as the contemporary analysis by R.S. Stafford, The Tragedy of the Assyrians (London: George Allen \& Unwin Ltd., 1935), remain important. For a recent re-evaluation of the sources from an Assyrian perspective, see Donabed, Reforging a Forgotten History.

41 Assyrian historiography is based largely on Yaquw bar Malek Ismail, Âturāyē w-trēy plāšè tbïlāyē, h.d., Āturāyē men 1914 hal 1945 ('Assyrians and the Two World Wars, i.e., Assyrians between 1914 and 1945'; Tehran: Maṭba'tā d-sī'ta seprāytā d-'allīmē Āturāyē, 1964); Yusuf Malek, The British Betrayal of the Assyrians (Chicago: The Assyrian National Federation and The Assyrian National League of America, 1935). 
patriarch and some kind of regional independence, and therefore fundamentally different from that of other Christian communities in Iraq. Many of the Assyrians, like the Chaldeans with whom they shared a long common history in northern Iraq, preferred non-preferential treatment by the Iraqi government and were inclined to acknowledge the state's power, relinquish dreams of a separate homeland, and allow restricting the clergy's powers to the spiritual realm. ${ }^{42}$

The contributions by Laura Robson and Hannah Müller-Sommerfeld address the importance of a refugee camp for displaced Assyrians and Armenians in understanding the dynamics of the failed inclusion of the Assyrians into the Iraqi state. The Ba'quba camp, not far from Baghdad, was set up under the responsibility of the League of Nations and administered by British officials. It arose from the need to cater to the tribal Assyrians who had been forced to flee first the Hakkari province (in today's eastern Turkey) to Urmia (in northwestern Iran), from where they joined the Russian and Armenian armies in their fight against Turkish and Kurdish troops. When the situation in Urmia deteriorated after the Russians retreated early in January 1918 and Turkish and Kurdish forces once more marched up to Urmia in Iran, many Assyrians decided to flee towards British-ruled territory in Iraq, preferring British protection opposed to Persian protection. In this period, the Assyrian leadership had been made to believe that the British would support not only resettlement in their ancestral homelands in Hakkari, but also some kind of Wilsonian semi-independence. Thus, for the Assyrians from Hakkari, the camp in Ba'quba essentially was a temporary provision before they could return to the north. ${ }^{43}$

While differing in their analysis of the causes, both Robson and MüllerSommerfeld underline the significance of the camp in creating a new minority identity for the Assyrians. In the camp, the Assyrians were treated as stateless refugees, who, being largely dependent on the British colonial administration for jobs, education, and sustenance, were inspired to re-invent themselves in the post-war era away from Iraqi society. Robson stresses the way in which the camp, by virtue of its specific organizational and spatial set-up, fostered

42 Murre-van den Berg, "Light from the East," and Müller-Sommerfeld in this volume. On the Chaldeans in this period little has been written so far, but see Wilmshurst, The Martyred Church.

43 For more detail, see the contributions by Robson and Müller-Sommerfeld in this volume; the standard work for this period is John Joseph, The Modern Assyrians; see also the overview work by Wilmshurst, The Martyred Church. The most detailed discussion of this episode, based on many new sources, is found in Hellot-Bellier, Chroniques de massacres annoncés; she also traces the history of the much contested British promises (497-506). 
separate 'national' identities for the Assyrians and the Armenians. The two groups were separated as much as possible from each other and from Iraqi society, with educational programs in the camp focusing on preparing pupils for a future return to a 'homeland' with some kind of separate existence from the Iraqi or Turkish states. Whereas Robson emphasizes the British agency in this respect, ${ }^{44}$ Müller-Sommerfeld, by studying the so far largely untapped archives of the League of Nations, shows that the Assyrians themselves were keen to fully employ the League of Nations' system of minority protection in their favor. Her study of the archives underlines the divisions within Assyrian society, not only between those in the camp (mostly from Hakkari) and those outside the camp (Assyrians that had always lived in what was to become the state of Iraq), but also among the Assyrians from Hakkari, who had conflicting regional and familial interests. Earlier tribal and regional subdivisions often translated into different political positions among those who contested the leadership of the patriarchal family.

In the final analysis, the outcome of the process was that the Ba'quba camp, instead of easing the transition from being stateless refugees to becoming integrated citizens of the Iraqi state, sanctioned their separate trajectories. Even after it had become clear (Lausanne Conference, 1922-1923, final decision in 1925) that the Assyrians would not be allowed to return to Hakkari, nor would they be granted (semi-)independence within the new borders of Iraq, both the British and the League of Nations failed to convince the Assyrians to come to terms with this loss. The deep chasm between the nationalist hopes of the Assyrian leadership, especially the party supporting the young patriarch Mar Shimun Eshai (in office 1920-1975), and the avowed aim of British and Iraqi government officials to integrate the Assyrians in a multi-ethnic and multi-religious Iraq, played a crucial role in developments leading up to the dramatic events of the summer of 1933. The patriarch was unwilling to consider proposals for the resettlement of the Hakkari Assyrians in other parts of northern Iraq, and even more unwilling to relinquish his temporal powers over the community and limit his leadership to the spiritual. Probably driven by fear of what might happen to the Assyrians once their British protectors had left Iraq, the patriarch refused to let the Hakkari Assyrians integrate into Iraqi society. Mar Shimon Eshai's refusal to adapt to the changing circumstances and instead to allow for the armed resistance of Assyrians in the north, were important factors in the chain of events that led to the massacre of Semele. This played out at a moment in time when power struggles in Iraq's administrative 
circles had destabilized the country and the events were easily framed as yet another indication of the Assyrian threat to Iraqi national unity. It was only towards the end of 1948 that the patriarch, who was forced into exile in 1933, officially relinquished his temporal powers and the Assyrian community in many ways became like other non-Muslim communities in Iraqi society: full citizens of an Arab state rather than a minority waiting for its full rights. ${ }^{45}$

The story does not end here, though. While the Assyrians from Ba'quba obtained Iraqi citizenship and settled in the north or in Baghdad, or emigrated to nearby Syria where many Hakkari Assyrians found a place to live, ${ }^{46}$ or places further away, the tensions surrounding their place in Iraqi society were not over. Though some of the most ardent Assyrian nationalists emigrated to Syria or the United States, the old separatist nationalism remained popular among Assyrians in the north, in the slipstream of Kurdish nationalism. Suffering with the Kurds under Saddam's genocide in the 1980s, the Assyrians profited from independence from Saddam's Iraq in the early 1990 s and were able to build up a Syriac (Aramaic)-based educational system and other cultural institutions. ${ }^{47}$ Different from the Armenian and Syriac refugees that settles in Syria and Lebanon, the Assyrians found it difficult to settle for a mere quietist minority existence. At the same time, full cultural and linguistic integration, such as sought after by many Chaldeans, was practically anathema to the Assyrians, even if individuals, especially after World War II, would make different choices.

Thus, in conclusion, one could attribute the Assyrians' clash with the Iraqi nation state to a combination of their well-developed and thoroughly modern sense of their own national identity (based on an older tradition of political, social, and cultural independence), and their displacement, vulnerability, and colonial complicity in the post-war era. In deciding what was the most impor-

45 See Müller-Sommerfeld, this volume; Joseph, The Modern Assyrians, $175 \mathrm{ff}$.

46 Shabo Talay, Die neuaramäischen Dialekte der Khabur-Assyrer in Nordostsyrien: Einführung, Phonologie und Morphologie (Semitica viva, Bd. 40; Wiesbaden: Harrasowitz, 2008).

47 On Assyrians and Chaldeans in the twentieth century, see Herman Teule, Les AssyroChaldéens. Chrétiens d'Irak, d'Iran et de Turquie (Turnhout: Brepols 2008); Heleen Murrevan den Berg, "The Syriac Churches," in Ken Parry, The Blackwell Companion to Eastern Christianity (Malden/Oxford/Victoria: Blackwell Publishing, 2007), 249-268; Wilmshurst, The Martyred Church; and J.F. Coakley, "The Church of the East since 1914," in J.F. Coakley and K. Parry, "The Church of the East: Life and Thought," Bulletin of the John Rylands University Library 78, no. 3 (1996): 179-198, Suha Rassam, Christianity in Iraq: Its Origins and Development to the Present Day (Herefordshire: Gracewing, 2005). 
tant factor in this, we must take into account Müller-Sommerfeld's observation that in addition to the Assyrians, two other groups in Iraq started using the vocabulary of minorities: the Kurds and the Baha'is. Other Christians and the Jews refrained from doing so; they, with whatever uncertainties they may have felt for their future, identified at least superficially with the nationalist definitions of Iraq, with its combination of Arabism and state secularism. Clearly, the state's emphasis on Arabic and Arabism excluded Kurds, who emphasized their own different ethnic identity; this was an exclusion that was mitigated only slightly by some cooptation of Kurds in the central government. The exclusion of the Baha'is reminds us that this state secularism was predicated on Islamic definitions of acceptable religions, and thus in practice mostly excluded newer religions such a Baha'ism. In hindsight we may say that this implicit Islamic premise of acceptable religious difference proved the starting point for more extremist interpretations at a later phase.

\section{Transnational Dynamics}

Meanwhile, another nation state in the making was to create its own minorities, inside and outside the country. The creation of the state of Israel, with the official backing of the United Nations, changed the rules of who belonged to the majority population overnight. This was the case in the confines of the new-born state of Israel, where many Palestinians were forced to flee during the war of 1948 and those that remained became minorities in a state that was predicated on Zionism, Judaism, and Hebrew. In reaction to this, Jewish communities in many places in the Middle East were cast as unwanted minorities, whether or not they identified with this new state and its non-Arabic identity, and whether or not they themselves preferred to see themselves as such. These events underline how issues of majority and minority are related not merely to the nation state as such, but to the nation state in its regional and transnational connections. That is, processes of minoritization and the success or failure of 'common grounds' cannot be understood without also taking into account the process of migration (caused by varying degrees of material violence as well as social, economic, and politic pressures) and the emergence of transnational communities.

As referred to above, World War I led to the emergence of a number of refugee communities of Syriac, Assyrian, and Armenian Christians, mostly from today's Turkey. These population movements changed the social dynamics of many places in the Arab Middle East: these Christians became minorities in urban areas such as Jerusalem, Beirut, Aleppo, Baghdad, Cairo, and Mosul, 
whereas the rural Jazirah region in northeast Syria was transformed by the influx of Christian farmers from eastern Anatolia and later by Hakkari Assyrians expulsed by Iraq. ${ }^{48}$ In addition, large groups of Syriacs, Assyrians and Armenians moved outside the region, to the Americas, to the southern states of the USSR, and to Europe. In the process they created ever expanding transnational networks with nodes both in and near their places of origin and throughout the rest of the world. These nodes and networks that were created in the interwar years made use of trajectories and expatriate communities that were established in the nineteenth and early twentieth centuries. Then too, violence and social pressure played a role in stimulating migration (the first large group left Lebanon/Syria after the massacres of 1860), though longstanding commercial networks (especially those created by Persian Armenians in the seventeenth century) and contacts in the Christian world (Catholic networks of the sixteenth century onwards and Protestant connections built in the nineteenth century) were just as important. ${ }^{49}$

Thus it is no surprise that these transnational networks play a role in many of the contributions to this volume even if these networks, as such, are not the principle theme. When one reads the articles in the volume from this perspective, one is inclined to assume that the rapid expansion of these transnational networks often impeded the further development of common ground that provides space for discussions about the common good. The transnational space that the Iraqi Jews created for themselves, in which they were culturally, familially, commercially, and religiously bound to Asia, Palestine, England, France, and America, made it easier to disconnect themselves from Iraq when societal pressures increased. Similarly for the Assyrians from Hakkari, whose ties with Russia, Lebanon, Europe, and America dated from before World War I.

48 Sedah Altuğ, "Sectarianism in the Syrian Jazira: Community, Land and Violence in the Memories of World War I and the French Mandate (1915-1939)" (PhD, Utrecht University, 2011); Talay, Shabo, Die neuaramäischen Dialekte der Khabur-Assyrer in Nordostsyrien. Einführung, Phonologie und Morphologie (Wiesbaden: Harrasowitz, 2008), idem, Neuaramäische Texte in den Dialekten der Khabur-Assyrer in Nordostsyrien (Wiesbaden: Harrasowitz, 2009).

49 Albert Hourani, Nadim Shehadi, The Lebanese in the World: A Century of Emigration (London: The Centre for Lebanese Studies, 1992), Naures Atto, Hostages in the Homeland, Orphans in the Diaspora: Identity Discourses among the Assyrian/Syriac Elites in the European Diaspora (Leiden: Leiden University Press, 2011), Murre-van den Berg, H.L. (2002), "Migration of Middle Eastern Christians to Western Countries and Protestant Missionary Activities in the Middle East. A Preliminary Investigation," in The Journal of Eastern Christian Studies [Formerly Het Christelijk Oosten] 54, 1-2, 39-49. 
The situation was somewhat different for the Catholics in Jerusalem and Palestine at large. While their connections to the French-Catholic world initially may have held them back in their identification with Arab and Palestinian nationalism, in later decades these wider Catholic networks stimulated their identification with the region, rather than with the West in general or France in particular. Thus, depending on the further religious and political developments within these networks, they either grew into alternative communities or into support structures for local identification. Though overall the Catholic (and the Protestant) network might have been more effective in stimulating local rootedness, in the end its effects are the same as with the other transnational networks. The mere existence of such networks made the communities vulnerable to accusations of disloyalty to the state, while at the same time these networks increased the access of the communities to opportunities outside the region.

In the period following World War II, the benefits of migration mostly went both ways, with the transnational connections and transcultural skills that came with it serving the Christian communities in the Middle East. When in the 1960 and 1970s the Arab countries were eager to take further steps on the road of cultural and economic westernization, it was often the Christians that functioned as cultural brokers. Christians were relatively well educated and much more acquainted with western mores and habits; they spoke the languages of the West as well as the languages of the region, in literal and metaphoric ways. As a result, they occupied crucial and highly visible positions in public life, in education, journalism, music, literature and arts, science and medicine, thus contributing actively and publicly to the creation of a common ground.

From the late 1970s onwards, however, this fragile equilibrium started to break down. The Christians' position as cultural brokers was challenged by the double effect of a quickly growing well-educated Muslim middle class that competed for the same jobs in societies that increasingly looked in other directions than Europe and America for ideological inspiration, cultural role models, and economic power, be it to Turkey, China or the Gulf..$^{50}$ At the same time, political instability in the region made for increased migration of the Christian communities. Palestinian Christians followed their co-religionist to

5o Tarek Mitri, "Christians in the Arab East: An Interpretation of Contemporary History," in Habib Badr, et al., Christianity: A History in the Middle East (Beirut: Middle East Council of Churches, 2005), 933 pp; Translated from: Al Masihiyya Abra Tärīkhihā fì al-Mashreq (Beirut: Middle East Council of Churches, 2001), 851-867; Najib George Awad, And Freedom Became a Public-Square: Political, Sociological and Religious Overviews on the Arab Christians and the Arabic Spring (Vienna/Berlin: LIT Verlag, 2012). 
the America's after the war of 1967 , when Israel occupied East Jerusalem and the West Bank. Massive migration from Lebanon started in 1975, when both Christians and Muslims fled the devastations wrought by the Civil War. Coptic Christians started to leave Egypt from the 1970s onwards, first to other places in the Middle East, then also to the America's, Europe, Australia and Africa. Meanwhile, the small Syriac community from Turkey was caught in the war between the Turkish army and the PKK (1980s-1990s). From 1990 onwards, political and economic pressures pressured Iraq's Christians to migrate, seeing ever increasing numbers from 2003 onwards when during what grew to be a straightforward civil war, Christians were targeted expressly, mostly by Sunni extremists.

All of this did not immediately break down the communality between Christians and Muslims that had been created in the first part of the twentieth century. Much of the structures and places of encounter remained intact. The combination, however, of numerical and cultural marginalization of the Christians with the increased political clout of the diaspora communities, made for a different dynamic, both within the Christian communities and between them and the rest of society. It is then that the concept of minority again becomes important. For the first time also those communities that for most of the twentieth century resisted the label of 'minority', seeing themselves as part of the 'majority' community of Arabs, such as the Copts, the Greek (Antiochian/Rum) Orthodox and Greek Catholics, started to use the label. As has been recently described by Saba Mahmood, the complex interplay of realizing that the equal rights that had been expected never fully materialized, the pressures of minority discourses originating in the diaspora communities and in international organizations, and the internal, Middle Eastern rhetoric about the state, all contributed to the minoritization of those Christians that, different from those displaced in the various wars, had never left their countries of origin and had always been loyal supporters of the Arab states. ${ }^{51}$

Much of the transnational dynamics affecting Jews and Christians in the Middle East is not so different from what happens in other parts of the world where a combination of socio-political, economic and cultural factors gave rise to large expatriate diasporic communities that maintain a connection to their homelands. There is one cultural factor, however, that is fairly unique, which is the fact Jerusalem and the surrounding region occupy a special place in three religions, the adherents of two of them together, Christianity and Islam, counting for over half of the world's population. Whereas certainly not every 
Christian or Muslim worldwide is invested in the so called 'holy places', at least part of the cultural and political interest in the region from other parts of the world can be explained by these cultural-religious connections. Much of the missionary and humanitarian efforts from Catholics and Protestants in the modern period arose from a heightened interest in the state of Christianity in the lands of its birth, trying to save and preserve it, not only for its own sake, but as much for that of global Christianity, many parts of which consider the Holy Land as part of their religious heritage. The rise of Zionism (including its Christian varieties) and the ensuing Israeli state further added to the global public with stakes in the region. While sometimes these global interests in the region have contributed to the creation of common ground, often the multiplicity of actors and stakeholders has exacerbated many of the processes of contestation and exclusion described above. ${ }^{52}$

Boum's article highlights the importance of Jerusalem as a cultural and political symbol for Christians and Moslems of the Middle East, taking the perspective of the disenfranchised youth of North Africa. Their hip hop songs sample the rich repertoire of cultural themes that were produced in earlier phases of Arab resistance to the Israeli occupation of Jerusalem, a repertoire that ranges from the violent and aggressive videos of Islamists, to the melancholy work of Fayrūz, the Christian Lebanese singer (Nihād Wadī` Haddād, b. 1934). However, while the texts and symbols of these North African musicians are explicitly aggressive and activist, overall the political and cultural effects of these videos remain limited. Not only is the number of people that watch these videos not as high as the topicality of the issue leads us to expect, but more importantly, their activist stance has little to no effect on the politics of North African states, while the rappers, even if they attract the attention of the security forces, do not seriously threaten the status quo. As such, the musicians are reproached by other young North African activists who would rather invest more time in real life political activism than in online cultural expressions. ${ }^{53}$

52 See, e.g. several articles in the edited volume Journal of Levantine Studies 3, no. 1 (2013), Steven Kaplan and Merav Mack's "Editors' Note", Galia Sabar, "Between Israel and the Holy Land, between the Global and the Local: The Role of African Initiated Churches within African Transnational Migration to Israel," Adoram Schneidleder, "The Imagined Christian Ecumene and the Quest for Return: Christian IDPs in Israel and the 2009 Visit of Benedict XVI," Michelle Syen, "E-Transnationalism: The Case of the Christian Zionist Community in Israel," and Steven Kaplan, "The Transnationalism of the Ethiopian Orthodox Tawahedo Church in the Holy Land."

For a discussion of the fast growing field of research on online cultural expressions and identity politics, see Boum's contribution in this volume. 
Meanwhile, the ongoing civil war in Syria, with constantly rising numbers of casualties, homeless refugees, and devastated urban landscapes, has produced its own varieties of global performances, with musical expressions intended to address the world's silence in the face of cultural and political disaster. A case in point is the controversial video clip produced by two Syrian sisters from Sweden, Faia and Rihan Younan from Aleppo. ${ }^{54}$ 'To our countries' (li-biladi) consists of a mixture of classically phrased political statements written and recited by Faia (an Edinburgh-trained journalist), and tied in with fragments of songs by Fayrūz sung by Rihan (including the song on Jerusalem discussed in Boum's volume); the video clip was shared widely, both in the West and the Middle East. The minimalist video conveys the pain over what is happening in the Middle East; it skillfully distributes blame without naming anyone in particular, and brings together in one nostalgic narrative the cases of Syria, Iraq, Lebanon, and Palestine while glossing over differences of religion and politics. While many people appreciated the sisters' efforts to bring the woes of the Arab world to the fore, critical voices soon chimed in, most importantly because the sisters were seen as supporting the Assad regime. Others criticized their perceived one-sided blaming of the West for the Middle East's problems, and yet others blamed the sisters for denying their 'Assyrian' background and glossing over the way in which the Assyrians were treated by the Arabs. Where the sisters and their crew thought they could transcend differences of religion, region, and ethnicity by creating hope built upon the idealized Middle East of Fayrūz's generation, others saw this as hopelessly naïve and old-fashioned, and in no way relevant to resolving the real conflicts in the Middle East. ${ }^{55}$ Indeed, verbal contests about how clips like this one contribute to lasting peace in the Middle East continue against the background of youth who take matters into their own hands by joining the armed struggle against the Assad regime and more generally against what is seen as the West oppressing Muslims.

54 YouTube, 'To our countries' (https://www.youtube.com/watch?v=4GO52ioxui8), posted 9 October 2014, 1,786,114 viewings (13 February 2015).

For more extensive discussions, in addition to the postings on YouTube, see http://www .taz.de/Youtube-Video-Li-Biladi/!148495/ (largely positive; last seen 28 January 2015), Eli Shalal, http://www.aljadid.com/content/twisted-logic-younan-sisters-and-julia-boutrossing-same-deceptive-tune (very critical; last seen 28 January 2015), building on an article by Martina Sabra on Qantara.de (http://de.qantara.de/inhalt/syrisches-antikriegs-video -to-our-countries-peinlicher-medienhype; last seen 28 January 2015); see also Daily Star (31 October 2014) http://www.dailystar.com.lb/News/Middle-East/2014/Oct-31/276015supporters-opponents-of-assad-in-viral-video-confrontation.ashx (last seen 28 January 2015). 
What then, does this mean for the dynamics between majorities and minorities in the states of the Middle East, what does this mean for the creation and maintenance of common ground? Most importantly, perhaps, the transnational and global stage of cultural practices is here to stay. Whether in the form of YouTube videos, online political activism, world politics, Christian Zionism and Catholic advocacy for Middle-Eastern Christians, or in the attempts by NGOS, UNHCR, and UNESCO to mitigate the worst effects of war and strife, or in violent jihadist actions, all actors perform on a global stage and seek a global public that is asked to choose sides. Even if much of that involvement does not go beyond 'liking' and 'retweeting', it considerably widens the circle of people that have a stake in the developments on the ground. Certainly, the positive side of this is the fact that abuses of power, gross injustice and oppression of minorities can find a hearing much quicker and in wider circles than before, putting extra pressure on governments to adjust their policies and protect minorities. At the same time, however, these global performers all too easy may lose sight of the complicated dynamics of local context, the value of silent diplomacy and saving face in difficult situations-valuing applause on the global scene over concrete results on the ground. Minorities of all kinds thus may suffer as much as gain from such global involvement, especially where the state is weak and unable to protect those who for political, cultural or religious reasons are not considered part of the majority that exemplifies the unity of the state.

\section{Conclusions}

The overview by Schroeter of Jews in the Middle East and the varied case studies that are brought to the fore in this volume vacillate between opposite positions, one in which we can see a wide range of possibilities of finding common ground and the other, which makes obvious the limits to that same endeavor. Yes, there is a common ground, but it is fragile and its survival is very much dependent on the circumstances. These circumstances therefore are important in the analyses of this volume, and indicate the importance of stable and strong states that allow for a variety of interpretations of the definition of and criteria for citizenship. These definitions and criteria must be enforced against those that challenge it by advocating mono-cultural, mono-ethnic, and mono-religious societies. The case studies also point to the importance of understanding how communities that are seen as minorities (whether they like it or not), deal with that minority status. Are they able to negotiate the boundaries of their separateness with a view towards the common good of 
these societies as a whole? Or do they, with or without outside support, focus on their own survival only and so willingly and unwillingly contribute to their isolation?

The case studies show that, time and again, common ground was found: in Arabic as the language of the nation, in shared educational and cultural activities, and in political parties and social activism, even though that sometimes also led to new fissures and schisms - schisms, however, not between the allto-easy essentialized boundaries between religious or ethnic communities, but between people with different opinions and different social and regional backgrounds. History tells of many occasions in which religion was not a hindrance to cooperation, when Jews and Christians, despite their numerical minority within a society that structures itself on religion, could function optimally in society at large. It is from these cross-cutting cleavages, and the ways in which these cleavages were bridged time and again, that we can draw hope for the future, even if today's trends seem bound towards greater uniformity and less tolerance towards those who do not fit. 